\title{
VIRTUALNE INTERAKTIVNE TURE KAO METOD POVEĆANJA KONKURENTNOSTI DESTINACIJA NA TURISTIČKOM TRŽIŠTU
}

\author{
Kristina Živanović, Kristina Mrkonja \\ Univerzitet u Kragujevcu - Fakultet za hotelijerstvo i turizam u Vrnjačkoj Banji, Srbija
}

\begin{abstract}
:
Pred turizmom, kao delom uslužnog sektora i jednim od generatora privrednog rasta zemlje, stoje brojni izazovi karakteristični za poslovanje u 21. veku. Poslovni imperativ je uključivanje različitih vrsta tehničkih uređaja i brojnih modaliteta informacionih tehnologija u poslovne aktivnosti, kako bi se stekao adekvatan nivo konkurentnosti na turističkom tržištu. Turistička destinacija, pored autentičnosti, adekvatne infrastrukture i efikasnog menadžmenta mora osigurati da će upravo ona dobiti „kupčev dinar“ i tako steći distinktivnu prednost na tržištu koje karakteriše veliki broj konkurenata. Jedan od načina je kreiranje i uključivanje virtualnih interaktivnih tura u marketinške aktivnosti i prihvatanje stava da ovaj vid savremene komunikacije sa potencijalnim gostom u velikoj meri može doprineti povećanju konkurentnosti destinacije na turističkom tržištu, kao i učvršćivanju lojalnih odnosa sa postojećim kupcima, odnosno turistima u destinaciji. Korišćenjem metoda izučavanja postojeće literature, u ovom radu biće analizirane osnovne teorijske odrednice turističke destinacije, ali će biti dat i kratak osvrt na savremene tendencije u turističkoj privredi i načinu na koji pomenute virtualne ture doprinose povećanju konkurentnosti destinacija na turističkom tržištu.
\end{abstract}

\author{
Key words: \\ Virtualne interaktivne ture, \\ konkurentnost turističe destinacije, \\ savremene tendencije, \\ turistička destinacija, \\ turističko tržište.
}

\section{UVOD}

Tržište na kojem posluju privredni subjekti iz domena turizma karakteriše konstantan rast, a visok stepen konkurencije daje mu novu dimenziju - intenziviranje napora privrednih subjekata da se u moru sličnih izbore za „kupčev dinar“.

Pored standardnih paketa usluga koje turisti kupuju kao što su prevoz, ishrana, noćenje i slično, poseban akcenat stavlja se i na samu odluku o kupovini specifičnog doživljaja u određenoj turističkoj destinaciji.

Današnji posetioci i turisti imaju dve bitne karakteristike - manjak slobodnog vremena usled dinamike i strukture života u 21. veku i ograničena finansijska sredstva koja mogu izdvojiti za putovanja što je posledica domaćih, međunarodnih i svetskih ekonomskih tokova sa zahtevom da se naprave prioriteti u pogledu kupovine pojedinih dobara za život, ali i onih luksuznijih, ekskluzivnijih materijalnih proizvoda i usluga.

Upravo zbog navedena dva epiteta odluku o posećivanju određene turističke destinacije, turista će doneti promišljeno i pažljivo.

Zahtevi turista i generalno promene u preferencijama i željama današnjih potrošača rezultiraju stvaranjem širokog spektra turističkih proizvoda, a samim tim i turističkih destinacija raznolikog karaktera - destinacije mračnog, lovnog, avanturističkog, eko, zdravstenog turizma i slično.
Zadovoljenje svih tih, specifičnih potreba, u velikoj meri olakšavaju informacione tehnologije - poslovni rečnik 21. veka i neizostavna stavka poslovanja gotovo svih privrednih subjekata na nivou domaće, međunarodne i svetske ekonomije.

Da bi se u značajnoj meri na strani turiste, a iz perspektive menadžmenta turističke destinacije, skratilo vreme od pojave potrebe za putovanjem do donošenja konačne odluke i izbora željene destinacije, specifičan produkt informacionih tehnologija - virtualne interaktivne ture - mogu osigurati „kupčev dinar“, postepeno kreirati bazu lojalnih turista i talas novih posetilaca.

\section{TURISTIČKA DESTINACIJA - OSNOVNE TEORIJSKE ODREDNICE, DEFINISANJE POJMA I TIPOLOGIJA TURISTIČKE DESTINACIJE}

Kao specifičan magnet za turistička kretanja i aktivnosti, turistička destinacija nameće postojanje više različitih stanovišta u pogledu teorijskog određenja pojma.

Etimološki, pojam destinacije potiče iz latinskog jezika (destinatio - određenje, opredeljenje, krajnji cilj, namera), sa druge strane osnovu za prihvatanje pojma turističke destinacije treba tražiti u pojmu turističkog mesta, odnosno mesta za odmor [1]. Može se zaključiti da turistička destinacija predstavlja ciljnu lokaciju turiste koju je on percipirao kao mesto za odmor. Pored ovakve percepcije, turistička destinacija u savremeno doba postaje i mesto za 
avanturu, konzumiranje specifične hrane, mesto zabave i slično.

Turistička destinacija predstavlja skup različitih komponenti koje zajedničkim delovanjem obezbeđuju zadovoljenje potreba turista. U tom smislu, turistička destinacija može se opisati kao lokacija skupa atraktivnosti i odnosnih turističkih objekata i usluga koje turista ili grupa turista bira da poseti ili koju ponuda odabira da promoviše, odnosno kao područje sa različitim prirodnim svojstvima, karakteristikama ili atraktivnostima koje privlače nelokalne posetioce - turiste i izletnike [2]. Za potrebe osnovnog analiziranja i navođenje elementarnih pojmova vezanih za turističku destinaciju korisno je aktivnosti temeljiti na navedenoj definiciji, sa bitnim dodatkom - pored prirodnih atraktivnosti, svojstva turističke destinacije mogu biti i antropogenog karaktera, što rezultira povećanjem broja lokaliteta koje se danas podvode pod pojam turističke destinacije.

Jednu od tipologija turističke destinacije moguće je dati na osnovu motiva koji turistu privlače u određenu destinaciju. Sa ovog stanovišta moguće je izdvojiti:

1. Primorske destinacije kao najmasovniji vid turističkih kretanja, sezonskog karaktera i sa izraženim elementima rekreacije, pri čemu su osnovni motivi za posetu ovakvih mesta odmor, topla mora i egzotične plaže.

2. Planinske destinacije privlače turiste u dve sezone - letnoj i zimskoj, karakteriše ih to što se turisti dugo zadržavaju u destinaciji, ali dolazi i do pojave takozvanih vikend aranžmana. Osnovni motiv za posetu ovakvim destinacijama jesu zimski sportovi, ali izražen je i aspekt zdravstvenog turizma kao i želja za odmorom od svakodnevnih obaveza.

3. Banjske destinacije su turističke destinacije sa dugom tradicijom. Osnovni motiv njihove posete jeste blagodet po zdravlje čoveka - termomineralne vode, reljef i klima.

4. Gradske destinacije se uglavnom odlikuju kulturnim motivima turističke privlačnosti, kao što su spomenici, muzeji, trgovi, koncerti, kulturna dešavanja i slično. Motivi za posetu mogu biti različiti, počev od razgledanja znamenitosti pa sve do detaljnijeg upoznavanja stranih kultura i specifičnih sadržaja [3].

\section{SAVREMENE TENDENCIJE NA TURISTIČKOM TRŽIŠTU I NJIHOV UTICAJ NA KONKURENTNOST TURISTIČKE DESTINACIJE}

Savremene tendencije na turističkom tržištu nameću brojne izazove sa kojima se menadžment turističke destinacije svakodnevno sreće prilikom obavljanja poslovnih aktivnosti.

U turizmu je neophodno kontinuirano inoviranje turističke ponude, jer turisti danas sve više teže novim turističkim proizvodima, novim destinacijama, novim doživljajima i iskustvima [4].

Turistička privreda, kao deo uslužnog sektora sve češće usvaja korišćenje informacionih tehnologija, kao neizostavnog elementa poslovanja [5].
Pojava informacionih tehnologija i način na koji su promenile tok poslovnih aktivnosti, nametnuo je korišćenje kanala marketinga turističke destinacije kao alata za unapređenje položaja same destinacije. Prema Buhalisu i Likati, organizacije zadužene za menadžment destinacije koriste platforme kao što su TISCover, VisitBritain $i$ Gulliver, za distribuciju njihovih svojstava i prezentovanje destinacije kao holitičkog entiteta [6].

Faktori iz političkog, demografskog, ekonomskog, sociološkog i tehnološkog okruženja navode turističku privredu ka trendovima novijeg karaktera koje je nužno slediti u cilju efikasnog i efektivnog obavljanja poslovnih aktivnosti i zadovoljenja potreba turista.

Na turizam promene na nivou svetske ekonomije, tehnologije, pravnog sistema i demografije odrazile su se na način koji diktira tempo stvaranja novih proizvoda, oblika disperzovanja i turističkih kretanja, kreativno pakovanje turističkih proizvoda i novu fizionomiju turističkog transporta. Ovi specifični i modfikovani sadržaji oblikuju turističku tražnju i ponudu, a turističkim destinacijama diktiraju nove uslove marketinga i ditribucije čime ih pretvaraju u dinamične procese.

Budući razvoj, novi trendovi i rapidni procesi na globalnom tržištu uvode specifičnosti u turizam koje moraju biti brzo prihvaćene, a sve sa ciljem da se odgovori na potrebe i želje potrošača u turizmu.

Među najznačajnijim faktorima koji oblikuju turizam novog doba, nalaze se takozvani eksterni faktori, odnosno grupa faktora koja ne proističe direktno iz turističke privrede. Eksterni faktori, koji nastaju kao posledica svetskih društveno-ekonomskih pravilnosti ostvaruju uticaj na turizam, a samim tim i na turističke destinacije. Ti faktori pre svega uključuju kretanje svetskog kapitala, demografske karakteristike, tehnološke inovacije, virtualni svet u sistemu informacionih tehnologija, rešavanje interesnog konflikta između razvoja turizma i očuvanja životne sredine i zdravlja ljudi [7].

Savremene tendencije na turističkom tržištu odražavaju se i na sposobnost destinacije da odgovori na izazove i zahteve iz konkurentskog okruženja, kao i da očuva specifičan nivo konkurentnosti i ukoliko okolnosti stvore uslov - da razvije distinktivnu prednost i zasnuje je na sadržajima koje će osigurati redovan priliv turista u destinaciju.

Konkurentnost se u literaturi označava kao sposobnost da se tržištu ponudi visoko percipirana vrednost, neutralizujući na taj način stalne negativne pritiske pet sila konkurencije:

1. pretnje konkurenata

2. pretnje supstituta

3. pregovaračku snagu kupca

4. pregovaračku snagu dobavljača

5. rivalitet između konkurenata [8].

Kako bi turistička destinacija osigurala konkurentsku prednost, evidentno je da mora biti sposobna da efikasno odgovara na pritiske konkurentskih sila i da bi na takvom tržištu doživela prosperitet u poslovanju i privlačenju turista mora da ima sadržaje koje konkurenti nemaju, ili pak sadržaje koji su u određenoj meri različiti od konkurentskih. 
Osnovni smerovi koje destinacijski menadžment u budućem razvoju i poslovanju treba da sledi jeste promena orijentacije od masovnog ka individualnom turiz$\mathrm{mu}$ - svaki turista je individualni potrošač sa specifičnim znanjima o turističkom proizvodu, očekivanjima i željama i zahtevima koje želi da realizuje, odnosno ispuni u konkretnoj turističkoj destinaciji.

\section{VIRTUALNE INTERAKTIVNE TURE - OSNOVNE KARAKTERISTIKE I NAČIN KORIŠĆENJA U TURIZMU}

Najznačajnije promene u poslovanju na turističkom tržištu događaju se zahvaljujući pojavi savremenih informacionih tehnologija. Razvoj informacionih tehnologija odražava se na poslovanje subjekata na turističkom tržištu kroz povećanje efektivnosti u poslovanju turističkih agencija, hotela i ostalih činilaca ukupne turističke privrede. Informacione tehnologije igraju ključnu ulogu u svim elementima poslovanja, ali poseban značaj ima sistem komunikacije i interakcije između preduzeća i njegovih potrošača, kao i ostalih subjekata na turističkom tržištu. Elektronska i on-line komunikacija je veoma bitna čak i za mala preduzeća. Ove tehnologije na prvom mestu omogućavaju da se uspostavi direktan kontakt sa klijentima, zatim smanjuju troškove „distribucije” usluga, a karakteriše ih efikasnost i velika brzina u obavljanju poslovnih operacija. U vezi sa tim, mnoga preduzeća koja se bave turizmom, počevši od turistčkih agencija, koriste različite inovacije u svom poslovanju i pokušavaju da se konstantno prilagode trendovima na tržištu. Budući trendovi turističkih aktivnosti moraju počivati na brzim promenama potrošačkih motiva, globalizaciji i regionalizaciji svetskog turističkog tržišta, zahtevima savremenog menadžmenta, tehničko-tehnološkim trendovima razvoja i uklapanja u svetski turistički pokret. Inovacije koje primenjuju preduzeća iz oblasti turizma odnose se i na kreiranje takozvanih virtuelnih tura, kroz koje potrošači na kreativan način mogu spoznati sve draži određenih destinacije, što će im svakako biti od velikog značaja prilikom opredeljenja za boravak u neku od njih [9].

Virtuelna tura je niz fotografija unutrašnjeg i spoljašnjeg prostora međusobno povezanih tako da posmatrač može da promeni ugao gledanja, zumira i kreće se kroz slike prostora, da se "virtuelno prošeta" i upozna objekat ili prostor. Fotografije koje se koriste za izradu virtuelnih tura su snimljene posebnom foto tehnikom koja omogućava snimak prostora u punom krugu od 360/180 stepeni i obrađene programima koji omogućavaju određenu interaktivnost sa posmatračem, promenu ugla gledanja prostorije ili prostora, zumiranje i dobijanje određenih informacija o objektima koji se vide na fotografiji. Zbog svoje interaktivnosti, virtuelne ture su trenutno jedan od najefikasnijih načina za vizuelni prikaz poslovnih i drugih objekata, gradova, parkova i sličnih mesta. [10].

Korišćenje ove tehnologije omogućava sasvim inovativan pristup u izradi web i desktop aplikacija zasnovanih na tehnologiji virtuelne realnosti. Za razliku od dosadašnjeg načina navigacije virtuelnih scena, novom tehnologijom je moguće istraživati i kretati se kroz prostor u smerovima napred, nazad, levo, desno, gore i dole. Takođe, moguće je učitavanje i interakcija sa 3D modelima, kolizija sa 3D objektima, nove animacije kamere kao i postavljanje interaktivnih elemenata u prostoru. Naravno, omogućena je integracija multimedijalnih sadržaja pa tako se u ovom projektima virtuelnih tura koriste MP3 plejer, vremenska prognoza, interaktivne listajuće PDF brošure, virtuelne prezentacije hotela i turističkih objekata, pretraživi poslovni imenik, selektor regija, opcija preporuke prijatelju putem socijalnih mreža i web pošte, interaktivna Google 3D mapa, interaktivna mapa lokacije, auto režim i mnoge druge [11].

Posredstvom medija, stalno smo izloženi slikama bližeg i daljeg sveta, nalazimo se u poziciji virtuelnih putnika kroz kibernitički prostor. Ta virtuelna putovanja mogu biti podsticaj i poziv za realna putovanja, ali često imaju smisao po sebi (ljudi vole da gledaju reportaže iz egzotičnih zemalja iako su svesni da verovatno nikada neće imati prilike da tamo odu, zbog nedostatka sredstava, vremena ili drugih razloga). Celokupna naša egzistencija se sve više virtuelizuje, sve veći deo sadržaja naše svesti, emocija i interesovanja dugujemo medijima. Veštačka realnost potiskuje fizičku realnost, a u izvesnom smislu ona čak postaje subjektivno realnija i važnija. Prosečan čovek veći deo života provodi u svetu medijskih slika, a istovremeno znatno više putuje virtuelnim prostorom nego onim realnim, geografskim (ovde se kao relevantan pokazatelj javlja odnos između vremena provedenog na putovanju i vremena provedenog u gledanju turistički relevantnih sadržaja na televiziji i internetu). Post-turista, znači putuje čak i kada ne napušta dom. On je sve više „nepokretni putnik" u fotelji, učauren u četiri zida svoje sobe sa pogledom na svet kroz „virtuelne prozore“.

Potrebno je imati na umu da turisti primećuju sve detalje prilikom odluke o destinaciji koju žele da posete. Upravo oni elementi koje ne očekuje, koji će mu dati novu ideju i omogućiti da svet oseti na drugačiji način, ostaće mu u svesti i asocirati u narednom periodu na odabir konkretne destinacije [12].

\section{VIRTUALNE INTERAKTIVNE TURE KAO METOD ZA STICANJE DISTINKTIVNE PREDNOSTI TURISTIČKE DESTINACIJE}

Turističke destinacije pritisnute konkurencijom moraju da pristupe temeljnoj reorganizaciji poslovnih aktivnosti i uvođenju informacionih i komunikacionih tehnologija. Internet i on-line poslovanje su najbolje opcije za poboljšanje odnosa sa turistima i privrednim subjektima. Da bi se poslovalo bez gubitaka i ostvarivao profit potrebno je konstantno pratiti kretanja na tržištu i pronalaziti nova rešenja. Internet nudi široke mogućnosti pa i ostvarivanje direktnog kontakta sa putnicima (turistima). U tom slučaju konkurencija prelazi na virtuelni nivo i logično je da odgovor na taj trend jeste usmeravanje ka eposlovanju [13].

Orijentacija ka inovaciji (uvođenju informacionih tehnologija) znači konstantnu, dugoročnu brigu za latentne potrebe sadašnjih i potencijalnih turista. To povlači, s druge strane, stvaranje superiornijih usluga u odnosu 
na konkurenciju da bi se potrebe turista zadovoljile. Turističke destinacije koje žele da unaprede poslovanje pristupiće inovaciji i prihvatiti e-poslovanje. U tom slučaju destinacijski menadžment izdvaja sredstva i uvodi nove tehnologije u poslovanje [14].

Međutim, da bi jedna turistička destinacija mogla konstantno da uvodi inovacije u svoje poslovanje (u ovom slučaju inovacije se odnose na uvođenje nove informacione tehnologije, kao što su virtuelne interaktivne ture), ona najpre mora da bude dobro pozicionirana na tržištu. U procesu pozicioniranja najvažnije je kako tržišne mete uočavaju imidž destinacije:

1. Ako tržište ne uoči imidž destinacije, imidž ne postoji.

2. Ako tržište ne veruje da ono što destinacija nudi turistima jeste korist, to tada nije korist.

3. Ako tržište ne veruje da korist može biti ostvarena, obećanje ostaje bez smisla.

4. Ako obećana korist nije uočena kao distinktivna u odnosu na korist koju obećava konkurencija, tada strategija diferenciranja neće biti uspešna.

Iz prethodno navedenog evidentno je da je jedan od osnovnih ciljeva upravljanja turističkim destinacijama kreiranje i održavanje konkurentske prednosti kroz konstantno unapređivanje razvoja turizma različitim vidovima inovacija. Virtuelne interaktivne ture kao jedan od vidova inovacija omogućavaju turističkim destinacijama koje ih koriste ostvarivanje konkurentske prednosti u odnosu na one destinacije koje svoju promociju vrše putem klasilčnih web sajtova. Ključ uspeha jedne turističke destinacije leži u kreiranju web sajtova sa virtuelnim interaktivnim turama. Destinacije koje koriste ovaj vid promocije ostvaruju konkurentsku prednost jer najveći broj zainteresovanih turista formira prvi utisak na osnovu izgleda web sajta. Takođe, virtualne ture smanjuju broj ranih napuštanja posetioca sajta, ali i povećavaju on-line rezervacije [15].

Pored klasičnih virtuelnih tura, mnoge turističke organizacije određenih destinacija svoje virtuelne ture baziraju na održivom razvoju turizma i upravo to je ono što ih izdvaja od drugih učesnika na turističkom tržištu.

Virtuelne interaktivne ture utiču na veću mogućnost i lakšu pristupačnost do informacija pre samog putovanja, kao i na sam postupak rezervacija usluga. Inovacije u vidu ovih tura pomeraju hijerarhijske odnose u marketinškoj praksi i korišćenje ovog vida tehnologije može predstavljati veliku kompetitivnu prednost za mnoge, pogotovo manje turističke destinacije. Tehnologija je imala i još uvek ima dramatičan uticaj na destinacijsku kompetitivnost i menadžeri turističkih destinacija moraju pratiti njen razvoj, jer se njihova kompetitivna prednost može vrlo brzo izmeniti.

\section{ZAKLJUČAK}

Turističku destinaciju možemo posmatrati kao grupu turističkih organizacija i različitih grupa koje rade zajedno ili sarađuju, ali sve njih vodi njihov vlastiti ekonomski interes. Upravo zbog toga je potrebna dobra koordinacija, saradnja i komunikacija među njima. Stepen saradnje ili takmičenja (konkurentnosti) između turističkih preduzeća i te kako utiče na način delovanja svake pojedinačne turističke destinacije. Saradnja jača turističke destinacije i njihov položaj na tržištu, jer sve vodi ka istom cilju, a visok stepen konkurentnosti može do neke mere takođe delovati pozitivno jer povećava inventivnost, kvalitet usluga i njihovu efikasnost. Virtualne ture koje nude informacije i ostale pogodnosti putnicima koji žele da korišćenjem Interneta uštede vreme, novčana sredstva i donesu pravilne odluke.

\section{Zahvalnice}

Posebno nam je zadovoljstvo izraziti zahvalnost docentu dr Snežani Milićević sa Fakulteta za hotelijerstvo i turizam u Vrnjačkoj Banji, pod čijim je mentorstvom i sugestijama ovaj rad nastao.

\section{LITERATURA}

[1] Popesku J. (2011), Menadžment turističke destinacije, Univerzitet Singidunum, Beograd, str. 25

[2] Popesku J. (2011), Menadžment turističke destinacije, Univerzitet Singidunum, Beograd, str. 26

[3] www.turizamiputovanja.com/motivka-tipologija-turistickih-destinacija/, pristupljeno 7.03.2014.

[4] Milovanović, V., Milićević, S., „Upravljanje turističkim proizvodima Srbije u funkciji unapređenja konkurentnosti na međunarodnom turističkom tržištu“, HiT MENADŽMENT, God. 2(1), Vrnjačka Banja: Fakultet za hotelijerstvo i turizam u Vrnjačkoj Banji, 2014, pp.38-48.

[5] Hinson R., Boateng R., "Perceived Benefits and Management Commitment to E-business Usage in Selected Ghanaian Tourism Firms", The Electronic Journal of Information Systems in Developing Countries, http://www.ejisdc. org , pristupljeno 22.02.2014.

[6] Minić N., Radović N., Knežević M., Primena i značaj informacionih sistema u poslovanju organizacija za upravljanje destincijom, Zbornik radova sa Sedmog naučnog skupa sa međunarodnim učešćem "Turizam: izazovi i mogućnosti”, Beograd 2012

[7] infoturizam.blogspot.com, pristupljeno 7.03.2014.

[8] Čerović S., Savremeni koncepti strategijskog upravljanja turističkom destinacijom, Zbornik radova sa Sedmog naučnog skupa sa međunarodnim učešćem “Turizam: izazovi i mogućnosti”, Beograd 2012

[9] Pavlović D., Spasić V., Efekti primene savremene informacione tehnologije u poslovanju malih preduzeća

[10] http://www.bitsoft.rs/virtuelna_tura.php, pristupljeno 11.03.2014.

[11] http://www.vrserbia.com/, pristupljeno 11.03.2014.

[12] Romelić J (2006)., Savremene tendencije u turizmu, hotelijerstvu i gastronomiji, Naučno-stručni časopis iz turizma, Univerzitet u Novom Sadu, Prirodno-matematički fakultet, Departmant za turizam i hotelijerstvo

[13] Ćosić D., Bogavac M., Elektronsko poslovanje i baze podataka, Univerzitet Union Beograd, Fakultet za industrijsko poslovni menadžment 
[14] Pavlović D., Spasić V., Efekti primene savremene informacione tehnologije u poslovanju malih preduzeća

[15] http://www.360vr.rs/, pristupljeno 11.03.2013

\section{Abstract:}

In front of the tourism, as a part of the service sector and one of the generators of economic growth of the country, there are numerous challenges characteristic for the business in the 21st century. Business imperative implies inclusion of different types of technical devices and numerous modes of information technology, in order to gain an adequate level of competitiveness in the tourism market. Besides authenticity, adequate infrastructure and efficient management, tourist destination must ensure that it will get the right "customer dinar" and gain a distinctive advantage on the market which is characterized by a large number of competitors. One of the ways is creation and inclusion of interactive virtual tours in marketing activities and acceptance of the view that this form of modern communication with potential guests can greatly contribute increasing the competitiveness of the destination on the tourism market, as well as making good relationships with existing loyal customers and tourists in one destination. Using the method of studying the existing literature, this work will analyze the main theoretical determinants of tourist destination, but also, it will give a brief overview of contemporary trends in the tourism industry. It will be shown the manner in which mentioned virtual tours contribute increasing the competitiveness of destinations on the tourist market.

\section{Key words:}

Virtual interactive tours, the competitiveness of tourist destinations, contemporary trends, tourist destinations, tourism market. 